\title{
A conversation with Bruce Beutler
}

A legend within the field of innate immunity, Dr. Bruce Beutler (Figure 1) of the University of Texas Southwestern Medical School is best known for two seminal discoveries: identifying mouse tumor necrosis factor and discovering Toll-like receptor 4, the receptor for lipopolysaccharide. With this discovery, later rewarded with the 2011 Nobel Prize in Medicine, we finally understood how immune cells could recognize and react to bacteria. The full interview, with many more stories on developing etanercept, searching landfills for sequencers, and falling in love with genetics can be seen on the JCI website, http://www.jci.org/ kiosk/cgm.

JCI: Could you start by telling me a little bit about where and how you grew up?

Beutler: I was born in Chicago, but from the age of two I was raised in Southern California. My father was a biomedical researcher himself, Ernest Beutler, a renowned hematologist with eclectic interests interested in the genetics of anemia, glycolipid storage diseases, iron deficiency, and cancer. Most definitely he encouraged my interest in science from an early age.

I started off with a broad interest in nature, and I remember being fascinated by animals from the time I was a small child, thinking how interesting it was that they could move and showed evidence of free will. I was just taken by the beauty of nature. At some point, my father tried to influence me by pointing out that all of my birding expeditions weren't really science; I was merely being observational, and he invited me to work in his lab. I was certainly eager, and from the age of 14, I started working in his laboratory through the summer and then on weekends thereafter during the school year. I learned how to assay erythrocyte enzymes, how to do electrophoresis in starch gels, and to purify proteins.

JCI: You went to college young, and finished very quickly.

Beutler: I was trying to emulate my father to some degree because he went to college at 15 and finished medical school at 21. I always set that as a standard to be followed for academic excellence, but also, I remember just being impatient to start practicing science instead of being mostly an observer and a trainee, and I thought remarkable things were happening. People were beginning to clone cDNAs by the time I was in college, and molecular biology was undergoing a revolution and I wanted to be a part of all that.

JCI: Why did you choose to go to medical school, and why University of Chicago?

Beutler: I applied to many medical schools, but I was only accepted to one. Maybe this was because I was only 18 years old when I was applying. Also, I was unabashedly saying to all the people who interviewed me that I was interested in science rather than clinical medicine. I think the attitude was, "Well in that case, why don't you get a PhD?" I had advice to the contrary from my father - he felt that if I wanted to be a biomedical scientist, I should study medicine. I should learn at least what the big challenges were, I should understand anatomy, physiology, pathology, pharmacology, and knowing all of those things I'd be in a position to work on almost any problem I chose.

JCI: You chose UT Southwestern for your internship and residency in neurology.

Beutler: There I did have some choices, and I ranked UT Southwestern first because I thought that if I was going to do a residency, it should be a tough residency - one where I would be challenged and learn all I could about internal medicine and then neurology - in the shortest possible time. I certainly was not disappointed in that regard. It was a stringent experience being an intern at Parkland Hospital.

JCI: After your residency, you decided to do post-doctoral research with Tony Cerami at Rockefeller. Your project was on cachectin, a putative mediator of wasting.

Beutler: When I arrived in that lab I had a choice to work either on cachectin or on non-enzymatic glycosylation in diabetes. I chose to work on the cachectin project because I felt I could purify the protein. When I began to assay it, and to define the best conditions for an assay, there was a strong signal, and I thought isolating the protein would be straightforward. In fact it did go quite quickly. It took about a year to purify cachectin to homogeneity and to sequence it.

JCI: It turned out to be the mouse version of tumor necrosis factor.
Beutler: I actually was surprised because it had been said in the lab that this had been ruled that out - that others had done assays for TNF activity in cachectin preparations and had found no relationship between the two. However, the most important part of the discovery was the fact that TNF, far from being a benign protein as portrayed by those using it for cancer chemotherapy, was a powerful inflammatory mediator, responsible for many of the effects of LPS. This led to the next phase of my work, in which I tried to find the receptor for LPS.

JCI: You transitioned back to Dallas to establish your first lab, as an HHMI-funded investigator wherein you switched focus from TNF to trying to sort out the LPS receptor.

Beutler: This was a gradual process. At first, it was something that I just wondered about. I was familiar with the $\mathrm{C} 3 \mathrm{H} / \mathrm{HeJ}$ mice that were endotoxin resistant. It was speculated quite widely that they had a mutation in the LPS receptor and nobody knew what that receptor was; it was peculiar that nobody understood how microbes were perceived in general - how macrophages, neutrophils, and other cells "knew" when an infection was in progress. The fact that nobody knew elevated the stature of the question in my mind. I first worked on it in a back burner sort of way. Starting maybe in about 1986 or ' 87 , we began cross-immunizing $\mathrm{C} 3 \mathrm{H} /$ $\mathrm{HeJ}$ mice with $\mathrm{C} 3 \mathrm{H} / \mathrm{HeN}$ cells and vice versa hoping to raise an antibody that would detect the difference. We never could. I thought maybe I could see a protein that was missing in the membrane fraction of $\mathrm{C} 3 \mathrm{H} / \mathrm{HeJ}$ macrophages, and this too was unsuccessful. We tried also cDNA cloning as a strategy to identify the critical gene, and I began incorporating more and more people into the project. But it was going nowhere and that was when I turned to genetics. Positional cloning was something I tried to avoid, but when I did start it, I became completely addicted to it. It was something so compelling, the idea that you could start with a strong phenotype, and gradually restrict the area of the DNA to a smaller and smaller region, and then clone all of it, and then find the gene. 
JCI: You covered about $90 \%$ of the critical region before you finally landed on TLR4.

Beutler: That was bad luck. We narrowed the interval. We started in the middle and worked toward the margins, because the middle would be the area of highest probability. And yet, it turned out to be quite close to one of the markers at the edge.

JCI: Can you describe how it felt to actually land on TLR4?

Beutler: It was something that happened at about 9:30 at night. I was at home looking over the day's results, and we'd been through a long dry spell where we had seen nothing in the way of genes. I was getting anxious, because I knew that either we had to find the mutation soon, or we had mapped incorrectly, and were simply in the wrong region of the genome. That was almost unthinkable.

Suddenly there was a very strong hit with the BLAST search, showing nearly perfect identity over 600 or so nucleotides with a particular expressed sequence tag. It was a stronger match than I had seen anywhere in the contig before. Within a few minutes, there was another hit with the same gene: Tolllike receptor 4 (TLR4). I was very excited - hyperventilating, shaking. I made a phone call immediately to Alexander Poltorak, who was the lead postdoc working with me on that project, and I could hardly tell him what I had seen because I was so excited about it. The reason to be excited was partly the nature of this gene, that it had leucine-rich repeats and therefore was similar to CD14, which was another protein known to be required for LPS sensing. It had a cytoplasmic domain similar to IL-1 receptor, which is an inflammatory receptor, well known to activate NF-KB. I had a vague memory, which I confirmed in a few minutes, that someone in France had earlier looked at Toll, the namesake of the gene family, and had found that it was needed for flies to resist fungal infection. And here I knew that TLR4, if this was indeed the gene, would be required to resist gramnegative bacterial infection; so it made a beautiful evolutionary story.

JCI: Shortly thereafter, you decided to move to California, to the Scripps Research Institute?

Beutler: I love California. It's where I grew up and it all seems very familiar to me. Also, my father was at Scripps. I'd always been close to him, talked to him

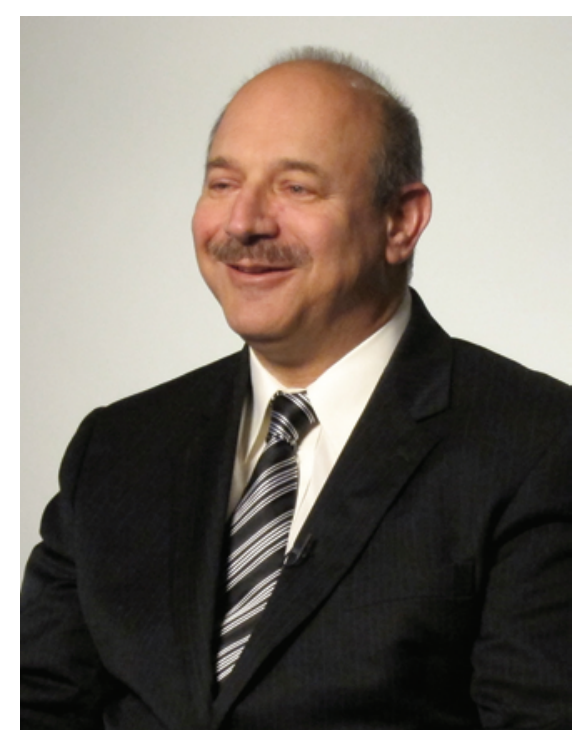

ing. The day before, I had seen my older brother, Earl, who also is in a biomedicallyrelated area, as he developed bibliographic software for reference retrieval program called Reference Manager. He had asked me in the casual chiding manner of a big brother, "You think you're going to win the Nobel Prize this year?"

That was a little bit on my mind and as I sat there jet-lagged, I looked at my cellphone and I saw a single e-mail that said "Nobel Prize" in the subject line. I thought, well, maybe this year they're sending out the announcement of the Prize to members of all national academies whom they frequently consult by e-mail. Then I opened the message and it was a letter that said that I had won the Nobel Prize! I hurried downstairs and I decided I ought to confirm it on the web. I tried to get into the nobelprize.org site but there was too much traffic, and so I went to Google News and typed my name. Initially, there was nothing. So, I thought, "Oh well, it really was a hoax". But I refreshed the browser, and within about 30 seconds, there were a hundred or so articles about me. First I called Betsy Layton, my administrative manager, who had been with me for the last 25 years and she started crying when she heard the news. And soon after, I called my brother, Earl, who didn't answer because he was asleep but I left a message on his phone saying that indeed I had won the Nobel Prize, but I was "only telling him because he had asked about it, because I'm a very modest person after all."

JCI: Would you advise any of your trainees to have the same drive and motivation you did to go after one singular problem with the same kind of tenacity that you had?

Beutler: I was often told by people, including by my father, that I was putting all of my eggs in one basket. But I must say in retrospect, if we hadn't been focused and committed to one problem, we probably wouldn't have got there. It was risky but I would counsel people to undertake highrisk projects and do them serially, rather than to work in parallel with a number of low-risk projects.

JCI: If you were to do it all over again, would you have chosen the same path?

Beutler: I think it worked out fairly well. But, if I hadn't been a biomedical researcher, very likely I would have been a naturalist and probably a writer.

\section{Ushma S. Neill}

